\title{
A 5' stem-loop and ribosome binding but not translation are important for the stability of Bacillus subtilis aprE leader mRNA
}

\author{
Gustav Hambraeus, Kaisa Karhumaa and Blanka Rutberg
}

Department of

Microbiology, Lund

University, Sölvegatan 12 ,

SE-223 62 Lund, Sweden
Author for correspondence: Gustav Hambraeus. Tel: +46 4622249 80. Fax: +46 46157839. e-mail: gustav.hambraeus@mikrobiol.lu.se

The Bacillus subtilis aprE leader is a determinant of extreme mRNA stability. The authors examined what properties of the aprE leader confer stability on an mRNA. The secondary structure of the aprE leader mRNA was analysed in vitro and in vivo, and mutations were introduced into different domains of an aprE leader-lacz fusion. The half-lives of the corresponding transcripts were determined and $\beta$-galactosidase activities were measured. Removal of a stem-loop structure at the 5 ' end or diminishing the strength of the RBS reduced the half-lives from more than $25 \mathrm{~min}$ to about $5 \mathrm{~min}$. Interfering with translation by abolishing the start codon or creating an early stop codon had no or little effect on mRNA stability. The authors conclude that a 5 ' stem-loop and binding of ribosomes are necessary for the stability of aprE leader mRNA. The present results, together with a number of other data, suggest that translation of a $B$. subtilis mRNA is generally not important for its stability; the situation seems different in Escherichia coli. It is further concluded that the calculated strength of a $B$. subtilis RBS cannot be used to predict the stability of the corresponding transcript.

Keywords: mRNA degradation, stability determinants

\section{INTRODUCTION}

The steady-state amount of an mRNA in a cell is a function of its rate of synthesis and its rate of degradation. Studies of mRNA degradation in Escherichia coli and other bacteria have shown that this is a highly regulated process, giving half-lives of individual mRNAs from less than one min to more than $30 \mathrm{~min}$ (Belasco, 1993). The half-lives of some mRNAs are influenced by growth stage and growth conditions (Paesold \& Krause, 1999; Vytvytska et al., 1998).

The general mechanism of mRNA degradation in E. coli is quite well understood (Grunberg-Manago, 1999; Rauhut \& Klug, 1999). Degradation proceeds in a $5^{\prime}$ to $3^{\prime}$ direction by successive endonucleolytic cleavages performed by RNase E (Cohen \& McDowall, 1997) or less commonly RNase III (Court, 1993; Régnier \& Grunberg-Manago, 1990). The resultant mRNA fragments are further processed by the $3^{\prime}$ to $5^{\prime}$ exoribonucleases RNase II and PNPase (Spickler \& Mackie,

Abbreviation: DMS, dimethyl sulphate.
2000) and finally degraded to mononucleotides by an oligoribonuclease (Ghosh \& Deutscher, 1999).

Much less is known about mRNA degradation in other bacteria. Nevertheless, studies in Bacillus subtilis have revealed significant differences in the degradation mechanism between this bacterium and E. coli. The two bacteria have different arsenals of ribonucleases, one important distinction being that there is no RNase E homologue in B. subtilis. While the $5^{\prime}$ region appears to be the most important determinant of mRNA stability in both bacteria, the same mRNA species can show different degradation patterns in B. subtilis and E. coli (Persson et al., 2000).

The B. subtilis aprE gene encodes the alkaline protease subtilisin (Ferrari et al., 1988). Transcription of aprE is under AbrB/Spo0A control (Strauch \& Hoch, 1993) and the gene is only expressed in stationary-phase bacteria. The aprE mRNA is unusually stable with a half-life exceeding $25 \mathrm{~min}$. We have recently shown that the determinants for aprE mRNA stability are located in the $5^{\prime}$ untranslated $58 \mathrm{nt}$ long leader sequence. aprE leaderlacZ fusion mRNA has a half-life of $\geqslant 25 \mathrm{~min}$ also in exponentially growing bacteria, showing that the ex- 
treme stability conferred by the aprE leader is not growth phase dependent (Hambraeus et al., 2000).

In the present work we have examined what properties of the aprE leader confer stability on an mRNA molecule. Our results show that a stem-loop structure at the $5^{\prime}$ end together with an intact RBS are important for the stability of the mRNA. However, whether the mRNA is translated or not has little or no effect on its half-life.

\section{METHODS}

Bacteria and plasmids. These are listed in Table 1.

Growth of bacteria. Bacteria were kept on TBAB plates and liquid cultures were grown in $\mathrm{LB}$ at $37^{\circ} \mathrm{C}$ on a rotary shaker at 200 r.p.m. For measurement of $\beta$-galactosidase activities and extraction of RNA, bacteria were grown to an $\mathrm{OD}_{600}$ of about 1.0 (mid-exponential phase). For determination of mRNA half-lives, the bacteria were incubated with $100 \mathrm{mg}$ rifampicin $1^{-1}$ for various times before samples were taken.

Genetic techniques. B. subtilis was grown to competence as described by Arwert \& Venema (1973). E. coli was made competent as described by Mandel \& Higa (1970).

Construction of strains. Plasmid pLUS2 is a derivative of pMD432 into which has been inserted a $g l p D$ promoter-aprE leader-lac $Z$ translational fusion. Transformation of $B$. subtilis BR95 with pLUS2 gave rise to strain LUS2 where the fusion has been integrated into the amyE locus (Fig. 1). Further, pLUS2 was used as template for PCRs with modified primers to introduce directed mutations into the aprE leader (Hambraeus et al., 2000). The same protocol was now employed to construct additional plasmids and strains with mutated aprE leader-lacZ fusions. The plasmid constructs were verified by DNA sequencing. The mutations introduced are shown in

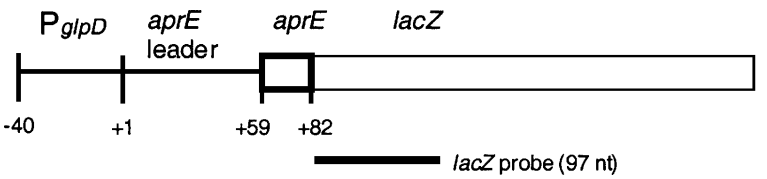

Fig. 1. Schematic representation of the insert of $B$. subtilis LUS2. +1 indicates the transcription start point.

Fig. 2, the primers used are listed in Table 2 and the resultant strains in Table 1.

$\boldsymbol{\beta}$-Galactosidase activity. $\beta$-Galactosidase activity was detected on TBAB plates containing $40 \mathrm{mg} \mathrm{X-Gal} 1^{-1}$. $\beta$-Galactosidase in liquid cultures was assayed according to Miller (1972) as described by Glatz et al. (1998).

RNA techniques. Total RNA was extracted as described by Putzer et al. (1992) with some modifications. A $15 \mathrm{ml}$ culture sample was added to a centrifuge tube filled to one-third with ice. The sample was centrifuged (5000 r.p.m. for $10 \mathrm{~min}$ ) and the pellet was resuspended in $0.4 \mathrm{ml}$ ice-cold TES buffer (50 mM Tris/HCl, $\mathrm{pH} 7 \cdot 5 ; 5 \mathrm{mM}$ EDTA; $50 \mathrm{mM} \mathrm{NaCl}$ ) and transferred to a tube containing $0.6 \mathrm{ml}$ acid phenol, $0.15 \mathrm{ml}$ chloroform and $0.8 \mathrm{ml} 0.1 \mathrm{~mm}$ silica beads. The mixture was vortexed in a Mini Bead Beater (Biospec Products) at full speed for $80 \mathrm{~s}$ and then centrifuged at $5000 \mathrm{r} . \mathrm{p} . \mathrm{m}$. for $5 \mathrm{~min}$. The aqueous phase was recovered and extracted with $0.6 \mathrm{ml}$ acidic phenol and $0.15 \mathrm{ml}$ chloroform and then once more with $0.7 \mathrm{ml}$ chloroform. Total RNA was finally precipitated from the aqueous phase with $1 / 10$ vol. $3 \mathrm{M} \mathrm{NaAc}, \mathrm{pH} 4 \cdot 8$, and 2.5 vols $95 \%$ ice-cold ethanol. After centrifugation and washing with ice-cold $70 \%$ ethanol, the pellet was resuspended in $0.2 \mathrm{ml}$ diethyl-pyrocarbonate-treated water. The quality of the RNA was controlled by electrophoresis in a $0.8 \%$ agarose gel with ethidium bromide.

Table 1. Bacterial strains and plasmids

\begin{tabular}{|c|c|c|}
\hline $\begin{array}{l}\text { Strain or } \\
\text { plasmid }\end{array}$ & Genotype/phenotype & Source/reference \\
\hline \multicolumn{3}{|l|}{ E. coli strains } \\
\hline XL-1 Blue & 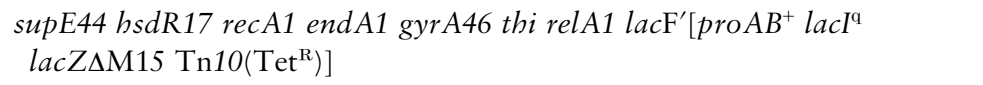 & Bullock et al. (1987) \\
\hline \multicolumn{3}{|l|}{$\begin{array}{l}\text { B. subtilis } \\
\text { strains }\end{array}$} \\
\hline BR95 & ilvC1 pheA1 trpC2 & Dept. Microbiology, Lund University \\
\hline LUS2 & $\begin{array}{l}\text { BR95 with insertion of a } g l p D \text { promoter-aprE leader-lacZ fusion into } \\
a m y E ; \mathrm{Cm}^{\mathrm{R}}\end{array}$ & Hambraeus et al. (2000) \\
\hline LUS7* & $\begin{array}{l}\text { As LUS2 but with A and T substitutions at }+23 \text { and }+27 \text { in the aprE } \\
\text { leader }\end{array}$ & This work \\
\hline LUS8* & As LUS2 but with an A substitution at +46 in the aprE leader & This work \\
\hline LUS9* & As LUS2 but with A substitutions at +46 and +48 in the $a p r E$ leader & This work \\
\hline LUS11* & As LUS2 but with the start codon GUG replaced by AAA & This work \\
\hline LUS12* & As LUS2 but with the fifth codon replaced by UAA & This work \\
\hline \multicolumn{3}{|l|}{ Plasmids } \\
\hline PMD432 & $\mathrm{Cm}^{\mathrm{R}} \mathrm{Ap}^{\mathrm{R}} ; \Delta a m y E::^{\prime} l a c Z$ & Dahl \& Meinhof (1994) \\
\hline pLUS2 & Derivative of pMD432; $\triangle a m y E:: g l p D$ promoter-aprE leader-lacZ fusion & Hambraeus et al. (2000) \\
\hline
\end{tabular}

* See Fig. 2. 


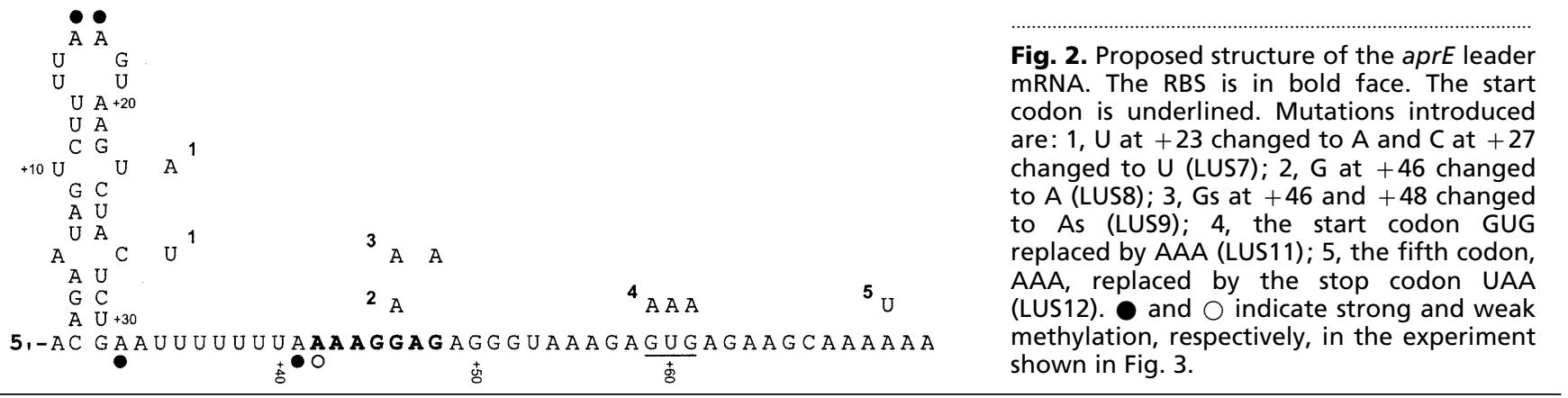

Table 2. Primer sequences

\begin{tabular}{|c|c|}
\hline Name & Sequence $\left(5^{\prime}-3^{\prime}\right)^{*}$ \\
\hline aprEconst & $\begin{array}{l}\text { TTG GAT CCT TTT AAA TAA AGT AAT ACT ATG GTA TAA TGG TTA } \\
\text { CAC AGA ATA GTC TTT TAA GTA AGT CTA CTC TG }\end{array}$ \\
\hline aprEconstS & TTG GAT CCT TTT AAA TAA AGT AAT ACT \\
\hline aprEBam2 & CAA GGA TCC GAT CCA CAA TTT TTT GCT TCTC \\
\hline aprEBulge & GTC TTT TAA GTA AGA CTA TTC TGA ATT TTT TTA \\
\hline aprEBulgeinv & TAA AAA AAT TCA GA $\underline{A}$ TAG $\underline{T C T}$ TAC TTA AAA GAC \\
\hline aprERBS1 & 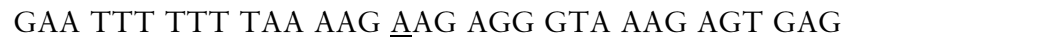 \\
\hline aprERBS1inv & 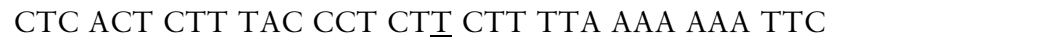 \\
\hline aprERBS2 & GAA TTT TTT TAA AAG $\underline{\text { AAA }} \underline{\bar{A}}$ AGG GTA AAG AGT GAG \\
\hline aprERBS2inv & 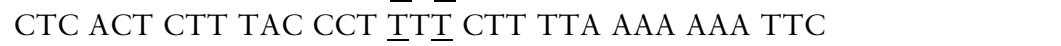 \\
\hline aprEnostart & $\begin{array}{l}\text { GGC GGA TCC GAT CCA CAA TTT TTT GCT TCT TTT TCT TTA CCC } \\
\text { TC }\end{array}$ \\
\hline aprEstop & GGC GGA TCC GAT CCA CAA TT $\underline{A}$ TTT GCT TCT CAC TCT TTA CCC \\
\hline lacZseq & GTT TTC CCA GTC ACG ACG TTG \\
\hline
\end{tabular}

$*$ The mutations introduced by the primers are underlined.

Electrophoresis of RNA for Northern blots was done as described by Thomas (1980). RNA $(10 \mu \mathrm{g})$ was added to each well. The RNA was blotted onto Hybond-N filters (Amersham). A single-stranded radioactive DNA probe for Northern blots (Fig. 1) was generated as previously described (Hambraeus et al., 2000). After hybridization, the radioactivity of the bands was quantified using a PhosphorImager (Molecular Dynamics). Primer extension analysis was performed according to the method of Ayer \& Dynan (1988). The primer used was lacZseq which is complementary to the $5^{\prime}$ end of the lac $Z$ part of the aprE leader-lacZ fusion mRNA.

Treatment of cells with dimethyl sulphate (DMS) was performed as described by Mayford \& Weisblum (1989). Culture samples of $15 \mathrm{ml}$ were transferred to a tube and $0.4 \mathrm{ml}$ DMS was added. After 4 min vigorous shaking, $10 \mathrm{ml}$ ice-cold TME buffer (100 mM Tris/HCl, pH 7.5; $100 \mathrm{mM} \beta$-mercaptoethanol; 5 mM EDTA) was added and RNA was extracted as described above. In parallel, cells that had not been incubated with DMS were treated in the same way and used as control.

\section{RESULTS}

\section{The secondary structure of the aprE leader mRNA}

The secondary structure of an RNA molecule can be estimated by using algorithms which search for the energetically most favoured structure. However, this procedure often yields several energetically similar but structurally different foldings of the same molecule. Moreover, since an RNA molecule may start to fold before its synthesis is completed, it could be locked in vivo in an energetically less favoured structure, which can be very different from the one(s) suggested by in silico experiments.

To facilitate studies on the aprE leader mRNA, Hambraeus et al. (2000) fused the aprE leader sequence to lac $Z$ and replaced the aprE promoter, which is active only in stationary phase cells, with the constitutive B. subtilis $g l p D$ promoter. The construct was integrated into the amyE locus of the B. subtilis chromosome (strain LUS2, Fig. 1). The aprE leader-lacZ fusion mRNA was as stable as the native aprE mRNA, showing that the aprE leader contains the stability determinants.

To get information about the in vivo secondary structure of the aprE leader mRNA, an exponentially growing culture of LUS2 was treated with DMS, which preferentially methylates unpaired adenine and cytosine residues. RNA was then extracted and used in primer extension experiments with a primer specific for the aprE leader-lacZ mRNA. Methylated nucleotides act as stop signals for reverse transcriptase and thus the reaction is prematurely terminated at the positions of 


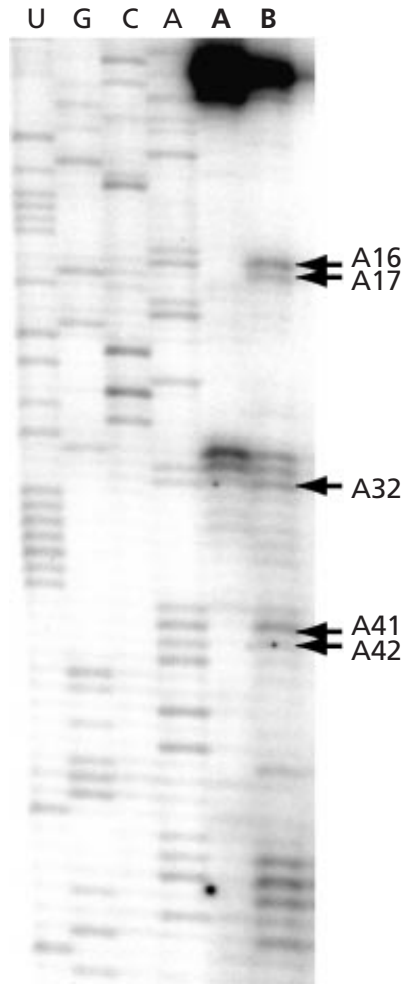

Fig. 3. Primer extension analysis of the aprE leader-lacZ mRNA methylated in vivo by DMS. Total RNA was extracted from growing LUS2 treated with DMS (B) or untreated (A). Methylated adenines are indicated. modified nucleotides (Fig. 3). A probable structure of the aprE leader mRNA predicted by the mfold programme (version 3.1, Mathews et al., 1999; Zuker et al., 1999) has a stable stem-loop structure at the very $5^{\prime}$ end (Fig. 2). Two of the six unpaired nucleotides in the loop are adenines. These residues, but no others, show up as stop signals in the DMS-treated RNA, supporting the presence of a stem-loop at the $5^{\prime}$ end. The stem-loop contains two bulges, one of which is formed by an adenine and a cytosine. These nucleotides were not seen to be methylated which we think may be because the small bulge is not readily accessible to DMS. A short stem-loop in the RBS region is also predicted and the primer extension experiments suggest methylation of three adenine residues at positions 41-43 which are believed to be part of the RBS. However, the loading of ribosomes on the mRNA must interfere with secondary structure formation in the RBS region and it could be assumed to be mostly single-stranded or melted in vivo upon engagement with the $16 \mathrm{~S}$ rRNA $3^{\prime}$ end (de Smit \& van Duin, 1990). Fig. 2 shows the structure of the aprE leader mRNA which is best compatible with the combined results of the computer predictions and the DMS experiments.

\section{Effects of directed mutations on the stability of aprE leader-lacZ mRNA}

One can distinguish three structural/functional domains in the aprE leader-lacZ mRNA: the $5^{\prime}$ stem-loop, the RBS and the start of the coding region. Mutations were
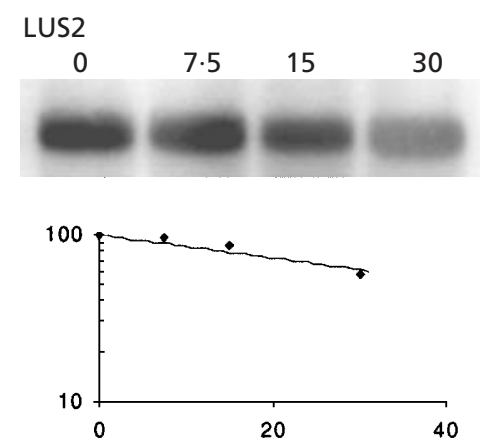

LUS9
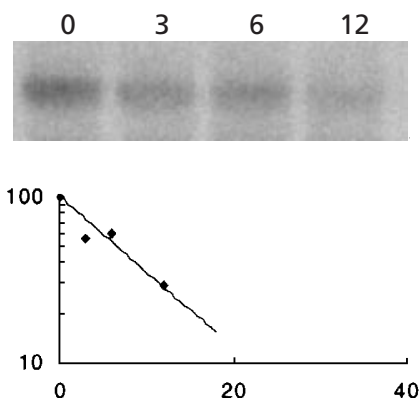
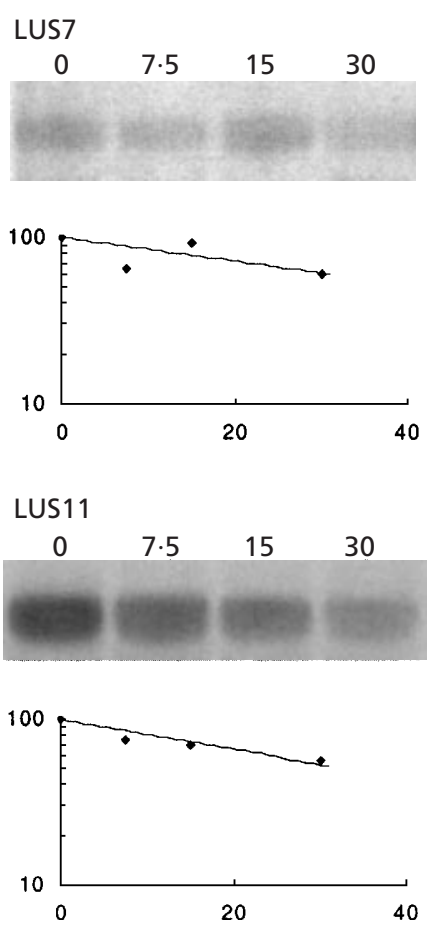
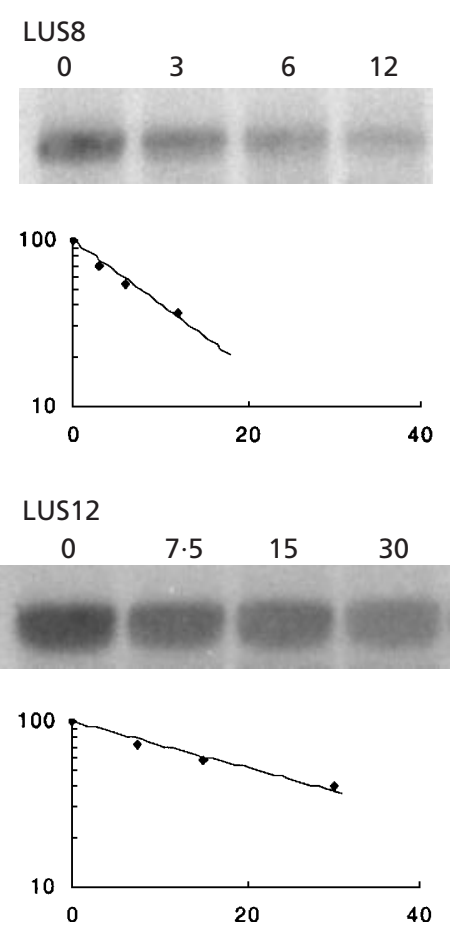

Fig. 4. Northern blot analysis and calculation of half-lives of the aprE leader-lacZ mRNAs. The bacteria were grown to $\mathrm{OD}_{600} 1 \cdot 0$, rifampicin was added and RNA was extracted at the times indicated $(\mathrm{min})$. The $y$-axes of the graphs indicate $\%$ remaining mRNA. The experiments were repeated at least twice with similar results. 
Determinants of B. subtilis aprE mRNA stability

Table 3. Half-lives and steady-state levels of aprE leader-lacZ mRNAs and pertaining $\beta$-galactosidase activities

\begin{tabular}{|c|c|c|c|c|c|c|}
\hline Strain & Mutation & $\begin{array}{c}\text { mRNA } \\
\text { half-life } \\
\text { (min) }\end{array}$ & $\begin{array}{l}\text { Effective } \\
\text { half-life } \\
(\min )^{*}\end{array}$ & $\begin{array}{l}\text { Relative } \\
\text { effective } \\
\text { half-life }\end{array}$ & $\begin{array}{c}\text { Relative } \\
\text { steady-state } \\
\text { level } \dagger\end{array}$ & $\begin{array}{c}\text { Relative } \beta \text { - } \\
\text { galactosidase } \\
\text { activity } \neq\end{array}$ \\
\hline LUS2 & None & $\geqslant 25$ & $\geqslant 14$ & 1 & 1 & 1 \\
\hline LUS7 & Removal of two bulges in the $5^{\prime}$ end stem-loop & $\geqslant 25$ & $\geqslant 14$ & 1 & $0 \cdot 07$ & $0 \cdot 2$ \\
\hline LUS8 & G of RBS $(+46)$ changed to $A$ & 6 & 5 & $0 \cdot 4$ & $0 \cdot 4$ & $0 \cdot 2$ \\
\hline LUS9 & Two Gs of RBS $(+46$ and +48$)$ changed to As & 6 & 5 & $0 \cdot 4$ & $0 \cdot 3$ & $0 \cdot 01$ \\
\hline LUS11 & Start codon GUG changed to AAA & 18 & 11 & $0 \cdot 8$ & $0 \cdot 9$ & $<0 \cdot 01$ \\
\hline LUS12 & Fifth codon changed to the stop codon UAA & 25 & 14 & 1 & $0 \cdot 9$ & $<0 \cdot 01$ \\
\hline
\end{tabular}

$*$ The effective half-life $\left(T_{1 / 2 \mathrm{E}}\right)$ is derived from the measured half-life $T_{1 / 2 \mathrm{M}}$ and the dilution due to cell growth (Belasco \& Brawerman, 1993): $T_{1 / 2 \mathrm{E}}=\left[\left(T_{1 / 2 \mathrm{M}}\right)^{-1}+\left(T_{\mathrm{D}}\right)^{-1}\right]^{-1}$. The generation time $\left(T_{\mathrm{D}}\right)$ was $30 \mathrm{~min}$.

† Determined from Northern blots (data not shown).

‡The $\beta$-galactosidase activity of LUS2 corresponded to $2 \mu \mathrm{mol}$ ONPG hydrolysed $\min ^{-1}(\mathrm{mg} \text { protein })^{-1}$. The extinction coefficient used was $4.5 \times 10^{3} \mathrm{M}^{-1} \mathrm{~cm}^{-1}$. The values represent the mean of at least two independent experiments. The deviation from the mean was less than $20 \%$.

introduced into each of these domains (Fig. 2) and the constructs were integrated into the amyE locus of the B. subtilis chromosome. The effects of the mutations on the stability and translation of the various mRNAs were then determined.

We have previously shown that two nucleotide substitutions, which are predicted to disrupt the stem-loop at the $5^{\prime}$ end, lead to at least a fivefold reduction of the half-life of the aprE leader-lacZ transcript. A similar reduction in half-life is also seen following removal of the stem-loop by deletion of $\mathrm{nt}+1$ to +25 (Hambraeus et al., 2000). To test the possibility that the bulges of the stem are a binding site for a protein that protects the mRNA from cleavage, we exchanged the nucleotides at positions +23 and +27 such that the bulges disappeared (Fig. 2). In the resultant strain, LUS7, the half-life of the aprE leader-lac $Z$ transcript was found to be the same as that of the wild-type, i.e. 25 min or longer (Fig. 4 and Table 3).

To interfere with ribosome binding, we mutated the RBS by changing the $G$ at position +46 to an A to give strain LUS8 and the Gs at +46 and +48 to As to give strain LUS9 (Fig. 2). The calculated free energies of interaction (see legend of Table 4) between the RBS and the $3^{\prime}$ end of $16 \mathrm{~S}$ rRNA of the wild-type and mutants are $\left(\mathrm{kcal} \mathrm{mol}^{-1}\right)$ : LUS2, $-8 \cdot 9$; LUS8, $-7 \cdot 3$; and LUS9, $-5 \cdot 2$. The half-lives of both mutant aprE leader-lacZ mRNAs were about 6 min compared to $25 \mathrm{~min}$ for the wild-type mRNA (Fig. 4 and Table 3).

Finally, mutations were introduced into the coding region of the aprE leader-lacZ mRNA. In strain LUS11, the GUG start codon was changed to AAA. In strain LUS12, a U was introduced in the first position of the fifth codon, changing it to the stop codon UAA. These mutations had little or no effect on the half-lives of the respective aprE leader-lac $Z$ transcripts, which were about $18 \mathrm{~min}$ for LUS11 and about $25 \mathrm{~min}$ for LUS12 (Fig. 4 and Table 3).
The steady-state level of an mRNA is a function of the rate of synthesis and the rate of removal. The rate of removal is often, for the sake of simplicity, taken to be the same as the rate of degradation of the mRNA, i.e. it is calculated from the half-life of the mRNA. However if the half-life of an mRNA is close to, or longer than, the generation time, the 'effective' half-life of the mRNA is derived from the half-life and the dilution due to cell growth (see legend of Table 3). The different aprE leader-lacZ fusions are all preceded by the constitutive $g l p D$ promoter. They should therefore be transcribed with the same efficiency and the steady-state levels of the respective transcripts should correspond to their effective half-lives, i.e. a decreased effective half-life should lead to a lowered steady-state level. The steady-state levels of the wild-type and mutant aprE leader-lacZ transcripts were measured and the values showed good correspondence between relative steady-state level and relative effective half-life for all strains except LUS7 (Table 3). In this strain the steady-state level was less than $10 \%$ of the wild-type level although the half-lives of the two transcripts were the same. By removing the bulges in the wild-type leader mRNA, we have created a strong transcriptional stop signal consisting of a 'perfect' stem-loop followed by a run of seven $U$ residues. We suggest that the majority of the aprE leader-lacZ transcripts initiated in LUS7 are prematurely terminated at this stop signal.

\section{Translation of wild-type and mutant aprE leader-lacZ transcripts}

The previous experiments have shown that mutations affecting the RBS destabilize the aprE leader-lacZ transcript whereas mutations that affect translation have little effect on mRNA half-lives. To confirm that the effects of the mutations on translation were the expected ones, we measured $\beta$-galactosidase activity in extracts from exponentially growing cells. The results of these experiments are shown in Table 3. It can be noted that 
Table 4. B. subtilis mRNAs with known half-lives

\begin{tabular}{|c|c|c|c|c|}
\hline mRNA & Sequence* & $\begin{array}{c}\Delta G_{0} \\
\left(\mathrm{kcal} \mathrm{mol}^{-1}\right)\end{array}$ & $\begin{array}{l}\text { Half-life } \\
(\text { min })\end{array}$ & Reference \\
\hline$a m y E$ & AAAUCAAAUAAGGAGUGUCAAGA AUG & $-8 \cdot 5$ & 5 & Hambraeus et al. (2000) \\
\hline aprE & UUUUUAAAAGGAGAGGGUAAAGA GUG & $-8 \cdot 9$ & $\geqslant 25$ & $\begin{array}{l}\text { Hambraeus et al. (2000); Resnekov } \\
\text { et al. (1990) }\end{array}$ \\
\hline$c l p C$ & AAAAGACAGGAGGAUGAAUCGAU AUG & $-10 \cdot 1$ & 2 & Allmansberger (1996) \\
\hline $\operatorname{csp} B$ & UGAUCGCUUUAGGAGGAAAUUUC AUG & $-11 \cdot 2$ & 2 & $\begin{array}{l}\text { Kaan et al. (1999); Graumann et al. } \\
\text { (1997) }\end{array}$ \\
\hline $\operatorname{csp} C$ & UUACACACUAGGAGGCAACAAAA AUG & $-10 \cdot 0$ & 2 & $\begin{array}{l}\text { Kaan et al. (1999); Graumann et al. } \\
\text { (1997) }\end{array}$ \\
\hline$c t c$ & AAAACGACA $\underline{A G A G G A U G G U G A A U ~ A U G ~}$ & $-9 \cdot 4$ & $<5$ & Jürgen et al. (1998) \\
\hline$g l p D$ & CGUGACAACAAGGAGGAAACGUA AUG & $-12 \cdot 2$ & $2 \cdot 3 \dagger$ & Glatz et al. (1996) \\
\hline groES & AUACUAUUGAGGAGGUUAUUUCA UUG & $-12 \cdot 7$ & 5 & Yuan \& Wong (1995) \\
\hline$g s i B$ & CACCAUUAAAGGAGGAAUUCAAA AUG & $-12 \cdot 2$ & 20 & Jürgen et al. (1998) \\
\hline$g s p A$ & AACAAAAAGGGAGAUGAAUACCA UUG & $-8 \cdot 5$ & $5-7$ & Jürgen et al. (1998) \\
\hline$o d h A B$ & UUUAAGUUGGGGGUAAUAUUCAA AUG & $-9 \cdot 7$ & $1 \cdot 5$ & Resnekov et al. (1992) \\
\hline$s a c R$ & ACAUAAAAAAGGAGACAUGAACG AUG & $-8 \cdot 9$ & $0 \cdot 6-2 \cdot 5$ & Pereira et al. (2001) \\
\hline$s d h$ & CUUAUCAAACAGGGGGUAAAGUA AUG & $-11 \cdot 2$ & $2 \cdot 6$ & Melin et al. (1989) \\
\hline$t h r S$ & UGCAAAAAAAAGGAGUGACAAAG AUG & $-8 \cdot 3$ & 2 & Condon et al. (1997) \\
\hline$x y n A$ & AAAAAUAUUAUAGGAGGUAACAU AUG & $-12 \cdot 2$ & 8 & Allmansberger (1996) \\
\hline
\end{tabular}

* The $23 \mathrm{nt}$ upstream of the start codon were aligned with the 3' end of the $16 \mathrm{~S}$ rRNA sequence (UUUCCUCCA) and the free energy was calculated using the programme RNA structure 3.6. The nucleotides that are predicted to be involved in the hybridization with $16 \mathrm{~S}$ rRNA are underlined.

† The half-life was determined at $45^{\circ} \mathrm{C}$. At $32^{\circ} \mathrm{C}$ the half-life was $4.5 \mathrm{~min}$.

LUS8 with one mutation in the RBS had about $20 \%$ of the wild-type $\beta$-galactosidase activity and about $40 \%$ of the wild-type steady-state amount of aprE leader-lacZ mRNA. Thus, the translational efficiency of $a p r E$ leader-lacZ transcripts in LUS8 was about half of that of the wild-type (LUS2). LUS9 with two mutations in the RBS showed a very low $\beta$-galactosidase activity but the half-life of its aprE leader-lacZ mRNA was the same as that of the LUS8 mRNA. No $\beta$-galactosidase activity was found in LUS11 where formation of the translational initiation complex must be severely impaired or in LUS12 carrying a premature stop codon. Still these mRNAs have a half-life close to that of the wild-type mRNA. The enzyme activities correlated well with the amount of $\beta$-galactosidase protein produced in the different strains as measured in Western blots (data not shown).

\section{DISCUSSION}

The B. subtilis aprE leader sequence contains determinants for extreme mRNA stability. The aim of this work was to define those determinants.

The first step in analysing the aprE leader mRNA was to determine its secondary structure. From computer predictions and in vivo DMS methylation experiments we derived the structure shown in Fig. 2, which has a stem-loop at its $5^{\prime}$ end.

Specific changes were introduced into different domains of the aprE leader-lacZ fusion mRNA, the first target being the $5^{\prime}$ stem-loop. Deletion of $\mathrm{nt}+1$ to +25 has been shown to result in a fivefold reduction of the halflife of aprE leader mRNA (Hambraeus et al., 2000), which indicates that the stem-loop is an important stability determinant. The two bulges of the stem-loop are apparently not required for stability (e.g. by binding a protecting protein) since their removal did not affect the half-life of the aprE leader-lac $Z$ transcript.

A stem-loop at the very $5^{\prime}$ end of the E. coli ompA mRNA is important for stability. Addition of a short single-stranded region to the $5^{\prime}$ end destabilizes the transcript (Arnold et al., 1998; Emory et al., 1992). Most likely this is because a single-stranded end facilitates or is required for binding of RNase $\mathrm{E}$ and, consequently, introduction of the first (rate-determining) endonucleolytic cleavage (Mackie, 2000). No RNase E homologue is known in B. subtilis (Kunst et al., 1997), although the existence of a similar enzyme has been postulated (Condon et al., 1997). It is possible that also the aprE leader mRNA stem-loop interferes with binding of an endonuclease, thus delaying an initial step in degradation of the mRNA.

Changing a G to an A in the RBS (LUS8) led to a fivefold decreased half-life of the aprE leader-lacZ mRNA. The amount of $\beta$-galactosidase produced by this mutant was also reduced about fivefold. Considering that there is less aprE leader-lacZ mRNA to be translated in LUS8 ( $40 \%$ of the wild-type steady-state amount), we can 
estimate that the mutation of LUS8 reduces the translational efficiency to about $50 \%$. Changing two Gs to As in the RBS (LUS9) caused no further decrease in the stability of the mRNA but the translational efficiency was reduced to a few per cent. Thus, reducing the translational efficiency about 30 -fold by mutating the RBS had no effect on mRNA stability.

An untranslated mRNA leader sequence from the Bacillus thuringiensis cryIIIA gene has been shown to stabilize in B. subtilis a lac Z gene fused to the $3^{\prime}$ end of the leader sequence. Stabilization requires the $129 \mathrm{nt}$ at the $3^{\prime}$ end of the leader mRNA. A strong RBS begins at -125 and is separated by one nucleotide from an AUG which, however, does not seem to be part of an ORF. The stabilizing effect is suggested to depend on binding of a $30 \mathrm{~S}$ ribosomal subunit and to be independent of translation of the downstream lac $Z$ gene (Agaisse \& Lereclus, 1996). A contribution of secondary structures in the 129 nt sequence was not considered. Similarly, a polypurine sequence from B. subtilis phage SP82 has been reported to stabilize an ermC or a lacZ gene fused to its $3^{\prime}$ end. Stabilization depended on an RBS which precedes a phage ORF but translation of the fused genes was not required (Hue et al., 1995). Earlier work on the ermA gene in B. subtilis showed that the stalling of ribosomes at a short ORF in the leader mRNA stabilized the ermA mRNA. The stalled ribosomes were suggested to block progression of mRNA degradation in a $5^{\prime}$ to $3^{\prime}$ direction (Sandler \& Weisblum, 1989). Abolishing the start codon or introducing an early stop codon in the aprE leader-lacZ fusion had little or no effect on mRNA stability. Neither of these mutants produced detectable amounts of $\beta$-galactosidase activity or protein. We conclude that translation has no effect on the stability of the aprE leader-lacZ mRNA.

In contrast, the stability of an E. coli mRNA generally seems to depend not only on ribosome binding but also on translation. Introduction of an early stop codon in the ompA gene or the bla gene destabilizes the respective transcripts indicating that translation is important for their stability (Nilsson et al., 1987). Increasing the speed of transcription of a gene (Joyce \& Dreyfus, 1998) or stalling ribosomes at artificially introduced rare codons (Deana et al., 1998) has also been shown to destabilize a transcript in E. coli. In neither case was initial binding of ribosomes to the RBS impaired but less of the mRNA was covered by ribosomes. A recent study of the regulation of the E. coli thrS gene also suggests a strong correlation between translation and stability of the $t h r S$ transcript (Nogueira et al., 2001). However, it has been claimed that also in E. coli, an efficient RBS, irrespective of translation of downstream sequences, can be sufficient to protect a transcript from rapid degradation (e.g. Wagner et al., 1994).

Although no general rule can be formulated concerning the importance of translation for mRNA stability in eubacteria, available facts all suggest that binding of ribosomes is important both in B. subtilis and E. coli. Jürgen et al. (1998) determined the half-life of B. subtilis
gsiB mRNA to be $20 \mathrm{~min}$ and weakening of the RBS decreased the half-life about fourfold. A comparison with two other sigma B-dependent mRNAs, gspA and $c t c$, also showed a correlation between the strength of the RBS and the stability of the mRNA. From these observations the general conclusion was drawn that the stronger the RBS, the more stable the corresponding mRNA.

We have surveyed the literature for determinations of B. subtilis mRNA half-lives. For each transcript we have calculated the energy of interaction between the RBS and the $3^{\prime}$ end of $16 \mathrm{~S}$ rRNA based on the $23 \mathrm{nt}$ preceding the start codon (Table 4). The stability of some of the mRNAs has been shown to be affected by, for example, stress (xynA; Allmansberger, 1996), a down-shift in temperature (cspB and cspC; Kaan et al., 1999) or growth phase (sdh; Melin et al., 1989) but, as far as we can deduce from the cited papers, the mRNA half-lives have been determined in bacteria growing at $37^{\circ} \mathrm{C}$.

Inspection of the data in Table 4 immediately reveals that there is no simple relation between the strength of interaction of the different RBSs with 16S rRNA and mRNA stability. In the present work we have shown that the native RBS is required but not sufficient for the high stability of the aprE leader-lacZ mRNA. Moreover, mutations that strongly reduced the strength of the RBS only reduced the stability of the mRNA to $6 \mathrm{~min}$, which is longer than the mean mRNA half-life in B. subtilis. For the groE gene and segments of the dnaK operon in B. subtilis, the presence of an inverted repeat, CIRCE, and its positioning relative the RBS have been found to affect the stability of the mRNAs (Yuan \& Wong, 1995; Homuth et al., 1999). An interaction between the RNA-binding antiterminator protein GlpP and the $g l p D$ leader mRNA in B. subtilis stabilizes $g l p D$ mRNA (Glatz et al., 1996). Clearly, the context of the leader sequence, possible secondary structures, or specific binding of proteins can be as important as the RBS in determining mRNA stability in $B$. subtilis.

We can conclude that the extreme stability of the aprE leader-lacZ mRNA is a function of a stem-loop structure at the $5^{\prime}$ end and a native RBS. The strength of interaction between the aprE RBS and 16S rRNA is less than average for the $B$. subtilis mRNAs presented in Table 4, emphasizing that the strength of an RBS cannot be used to predict the stability of a B. subtilis mRNA. When comparing B. subtilis with E. coli, it seems that translation is important for the stability of most E. coli mRNAs but unimportant for the stability of B. subtilis mRNAs. Whether this difference has any relation to the fact that an identical mRNA can have a very different half-life in the two species (Persson et al., 2000) is unknown.

\section{ACKNOWLEDGEMENTS}

This project was supported by grants from the Emil and Wera Cornell Foundation. We thank Lars Hederstedt and Claes von Wachenfeldt for critically reading the manuscript. 


\section{REFERENCES}

Agaisse, H. \& Lereclus, D. (1996). STAB-SD: a Shine-Dalgarno sequence in the $5^{\prime}$ untranslated region is a determinant of mRNA stability. Mol Microbiol 20, 633-643.

Allmansberger, R. (1996). Degradation of the Bacillus subtilis xynA transcript is accelerated in response to stress. Mol Gen Genet 251, 108-112.

Arnold, T. E., Yu, J. \& Belasco, J. G. (1998). mRNA stabilization by the ompA 5' untranslated region: two protective elements hinder distinct pathways for mRNA degradation. RNA 4, 319-330.

Arwert, F. \& Venema, G. (1973). Transformation in Bacillus subtilis: fate of newly introduced transforming DNA. Mol Gen Genet 123, 185-198.

Ayer, D. E. \& Dynan, W. S. (1988). Simian virus 40 major late promoter: a novel tripartite structure that includes intragenic sequences. Mol Cell Biol 8, 2021-2033.

Belasco, J. G. (1993). mRNA degradation in prokayotic cells: an overview. In Control of Messenger RNA Stability, pp. 31-52. Edited by J. G. Belasco \& G. Brawerman. San Diego, CA: Academic Press.

Belasco, J. G. \& Brawerman, G. (1993). Experimental approaches to the study of mRNA decay. In Control of Messenger RNA Stability, pp. 475-493. Edited by J. G. Belasco \& G. Brawerman. San Diego, CA: Academic Press.

Bullock, W. O., Fernandez, J. M. \& Short, J. M. (1987). XL1-Blue: a high efficiency plasmid transforming RecA Escherichia coli strain with beta-galactosidase selection. Biotechniques 5, 376378.

Cohen, S. N. \& McDowall, K. J. (1997). RNase E: still a wonderfully mysterious enzyme. Mol Microbiol 23, 1099-1106.

Condon, C., Putzer, H., Luo, D. \& Grunberg-Manago, M. (1997). Processing of the Bacillus subtilis thrS leader mRNA is RNase E-dependent in Escherichia coli. J Mol Biol 268, 235-242.

Court, D. (1993). RNA processing and degradation by RNase III. In Control of Messenger RNA Stability, pp. 71-116. Edited by J. G. Belasco \& G. Brawerman. San Diego, CA: Academic Press. Dahl, M. K. \& Meinhof, C. G. (1994). A series of integrative plasmids for Bacillus subtilis containing unique cloning sites in all three open reading frames for translational lacZ fusions. Gene 145, 151-152.

Deana, A., Ehrlich, R. \& Reiss, C. (1998). Silent mutations in the Escherichia coli ompA leader peptide region strongly affect transcription and translation in vivo. Nucleic Acids Res 26, 4778-4782.

de Smit, M. H. \& van Duin, J. (1990). Secondary structure of the ribosome binding site determines translational efficiency: a quantitative analysis. Proc Natl Acad Sci US A 87, 7668-7672.

Emory, S. A., Bouvet, P. \& Belasco, J. G. (1992). A $5^{\prime}$-terminal stem-loop structure can stabilize mRNA in Escherichia coli. Genes Dev 6, 135-148.

Ferrari, E., Henner, D. J., Perego, M. \& Hoch, J. A. (1988). Transcription of Bacillus subtilis subtilisin and expression of subtilisin in sporulation mutants. J Bacteriol 170, 289-295.

Ghosh, S. \& Deutscher, M. P. (1999). Oligoribonuclease is an essential component of the mRNA decay pathway. Proc Natl Acad Sci US A 96, 4372-4377.

Glatz, E., Nilsson, R.-P., Rutberg, L. \& Rutberg, B. (1996). A dual role for the Bacillus subtilis glpD leader and the GlpP protein in the regulated expression of $g l p D$ : antitermination and control of mRNA stability. Mol Microbiol 19, 319-328.

Glatz, E., Persson, M. \& Rutberg, B. (1998). Antiterminator protein GlpP of Bacillus subtilis binds to $g l p D$ leader mRNA. Microbiology 144, 449-456.

Graumann, P., Wendrich, T. M., Weber, M. H., Schroder, K. \& Marahiel, M. A. (1997). A family of cold shock proteins in Bacillus subtilis is essential for cellular growth and for efficient protein synthesis at optimal and low temperatures. Mol Microbiol 25, 741-756.

Grunberg-Manago, M. (1999). Messenger RNA stability and its role in control of gene expression in bacteria and phages. Annu Rev Genet 33, 193-227.

Hambraeus, G., Persson, M. \& Rutberg, B. (2000). The aprE leader is a determinant of extreme mRNA stability in Bacillus subtilis. Microbiology 146, 3051-3059.

Homuth, G., Mogk, A. \& Schumann, W. (1999). Post-transcriptional regulation of the Bacillus subtilis dnaK operon. Mol Microbiol 32, 1183-1197.

Hue, K. K., Cohen, S. D. \& Bechhofer, D. H. (1995). A polypurine sequence that acts as a $5^{\prime} \mathrm{mRNA}$ stabilizer in Bacillus subtilis. J Bacteriol 177, 3465-3471.

Joyce, S. A. \& Dreyfus, M. (1998). In the absence of translation, RNase E can bypass $5^{\prime}$ mRNA stabilizers in Escherichia coli. J Mol Biol 282, 241-254.

Jürgen, B., Schweder, T. \& Hecker, M. (1998). The stability of mRNA from the gsiB gene of Bacillus subtilis is dependent on the presence of a strong ribosome binding site. Mol Gen Genet 258, 538-545.

Kaan, T., Jürgen, B. \& Schweder, T. (1999). Regulation of the expression of the cold shock proteins CspB and CspC in Bacillus subtilis. Mol Gen Genet 262, 351-354.

Kunst, F., Ogasawara, N., Moszer, I. \& 149 other authors (1997). The complete genome sequence of the Gram-positive bacterium Bacillus subtilis. Nature 390, 249-256.

Mackie, G. A. (2000). Stabilization of circular rpsT mRNA demonstrates the $5^{\prime}$-end dependence of RNase $\mathrm{E}$ action in vivo. J Biol Chem 275, 25069-25072.

Mandel, M. \& Higa, A. (1970). Calcium-dependent bacteriophage DNA infection. J Mol Biol 53, 159-162.

Mathews, D. H., Sabina, J., Zuker, M. \& Turner, D. H. (1999). Expanded sequence dependence of thermodynamic parameters improves prediction of RNA secondary structure. J Mol Biol 288, 911-940.

Mayford, M. \& Weisblum, B. (1989). Conformational alterations in the erm $\mathrm{C}$ transcript in vivo during induction. EMBO J 8, 4307-4314.

Melin, L., Rutberg, L. \& von Gabain, A. (1989). Transcriptional and posttranscriptional control of the Bacillus subtilis succinate dehydrogenase operon. J Bacteriol 171, 2110-2115.

Miller, J. H. (1972). Experiments in Molecular Genetics. Cold Spring Harbor, NY: Cold Spring Harbor Laboratory.

Nilsson, G., Belasco, J. G., Cohen, S. N. \& von Gabain, A. (1987). Effect of premature termination of translation on mRNA stability depends on the site of ribosome release. Proc Natl Acad Sci U S A 84, 4890-4894.

Nogueira, T., de Smit, M., Graffe, M. \& Springer, M. (2001). The relationship between translational control and mRNA degradation for the Escherichia coli threonyl-tRNA synthetase gene. J Mol Biol 310, 709-722.

Paesold, G. \& Krause, M. (1999). Analysis of $r p o S$ mRNA in Salmonella dublin: identification of multiple transcripts with growth-phase-dependent variation in transcript stability. $J$ Bacteriol 181, 1264-1268. 
Pereira, Y., Chambert, R., Leloup, L., Daguer, J. P. \& Petit-Glatron, M. F. (2001). Transcripts of the genes $s a c B$, amyE, sacC and $c s n$ expressed in Bacillus subtilis under the control of the $5^{\prime}$ untranslated $s a c R$ region display different stabilities that can be modulated. Microbiology 147, 1331-1341.

Persson, M., Glatz, E. \& Rutberg, B. (2000). Different processing of an mRNA species in Bacillus subtilis and Escherichia coli. J Bacteriol 182, 689-695.

Putzer, H., Gendron, N. \& Grunberg-Manago, M. (1992). Coordinate expression of the two threonyl-tRNA synthetase genes in Bacillus subtilis: control by transcriptional antitermination involving a conserved regulatory sequence. EMBO J 11, 3117-3127.

Rauhut, R. \& Klug, G. (1999). mRNA degradation in bacteria. FEMS Microbiol Rev 23, 353-370.

Régnier, P. \& Grunberg-Manago, M. (1990). RNase III cleavages in non-coding leaders of Escherichia coli transcripts control mRNA stability and genetic expression. Biochimie 72, 825-834.

Resnekov, O., Rutberg, L. \& von Gabain, A. (1990). Changes in the stability of specific mRNA species in response to growth stage in Bacillus subtilis. Proc Natl Acad Sci U S A 87, 8355-8359.

Resnekov, O., Melin, L., Carlsson, P., Mannerlov, M., von Gabain, A. \& Hederstedt, L. (1992). Organization and regulation of the Bacillus subtilis odh $A B$ operon, which encodes two of the subenzymes of the 2-oxoglutarate dehydrogenase complex. Mol Gen Genet 234, 285-296.

Sandler, P. \& Weisblum, B. (1989). Erythromycin-induced ribosome stall in the ermA leader: a barricade to $5^{\prime}-$ to- $3^{\prime}$ nucleolytic cleavage of the ermA transcript. J Bacteriol 171, 6680-6688.

Spickler, C. \& Mackie, G. A. (2000). Action of RNase II and polynucleotide phosphorylase against RNAs containing stemloops of defined structure J Bacteriol 182, 2422-2427.

Strauch, M. A. \& Hoch, J. A. (1993). Transition-state regulators: sentinels of Bacillus subtilis post-exponential gene expression. Mol Microbiol 7, 337-342.

Thomas, P. S. (1980). Hybridization of denatured RNA and small DNA fragments transferred to nitrocellulose. Proc Natl Acad Sci U S A 77, 5201-5205.

Vytvytska, O., Jakobsen, J. S., Balcunaite, G., Andersen, J. S., Baccarini, M. \& von Gabain, A. (1998). Host factor I, Hfq, binds to Escherichia coli ompA mRNA in a growth rate-dependent fashion and regulates its stability. Proc Natl Acad Sci US A 95, 1411814123.

Wagner, L. A., Gesteland, R. F., Dayhuff, T. J. \& Weiss, R. B. (1994). An efficient Shine-Dalgarno sequence but not translation is necessary for lacZ mRNA stability in Escherichia coli. J Bacteriol 176, 1683-1688.

Yuan, G. \& Wong, S. L. (1995). Regulation of groE expression in Bacillus subtilis: the involvement of the sigma A-like promoter and the roles of the inverted repeat sequence (CIRCE). J Bacteriol 177, 5427-5433.

Zuker, M., Mathews, D. H. \& Turner, D. H. (1999). Algorithms and thermodynamics for RNA secondary structure prediction: a practical guide. In RNA Biochemistry and Biotechnology, pp. 11-43. NATO ASI Series, High Technology, vol. 70. Edited by J. Barciszewski \& B. F. C. Clark. Dordrecht: Kluwer.

Received 19 November 2001; revised 18 January 2002; accepted 5 February 2002. 